\title{
Science for Earthquake Risk Reduction
}

Since the beginning of the 21 st century the impacts of earthquakes and other geohazard-related disasters have risen rapidly: the 2004 Sumatra-Andaman earthquake and tsunamis, the 2005 Kashmir earthquake, the 2008 Wenchuan earthquake and induced landslides, the 2010 Haiti earthquake followed by a cholera outbreak, the 2011 Tohoku earthquake, tsunamis and flooding followed by the Fukushima Daiichi nuclear accident, and the 2015 Nepal earthquake and landslides (e.g., IsmailZadeh et al., 2014; Cutter et al., 2015). The vulnerability of our civilization to geohazard events is still growing partly due to the increase in the number of vulnerable objects and clustering of populations and infrastructure in the areas prone to geohazard events.

Understanding of disaster risk comes from recent advances in natural and social sciences, engineering, and applied research. Particularly, advances in lithosphere dynamics (e.g., Cloetingh et al., 2020), based on Earth observations, analyses, and modelling, improve the understanding of hazardous event occurrences. Earthquake assessments are supported by scientific evidences from seismology, geology, geodesy, geophysics, electromagnetism, hydrology, soil science, and by models and forecasting of extreme events. Engineering and science-based technological development contribute to improvements of earthquake-resistant constructions. Studies of physical and social vulnerabilities, exposure, capacities, and resilience help in assessing disaster risk and in preparing, responding, and adapting to possible disruptions due to disasters.

Meanwhile, despite the advances and knowledge accumulated, disasters continue affecting societies. Reducing disaster risks using scientific knowledge is a foundation for sustainable development (Beer and Ismail-Zadeh, 2003; Cutter et al. 2015). Our knowledge about earthquakes and their interaction with human systems is lacking in some important areas and is being challenged by the unforeseen or unknown repercussions of a rapidly changing and increasingly interdependent world (Ismail-Zadeh et al., 2017).

\section{Earthquake Hazards}

Although the majority of world greatest earthquakes occur at subduction zones (Stern, 2002), large earthquakes happen also in highly-populated continental collision or rift zones, such as the Tibet-Himalayan, Apennines, south-eastern Carpathians, and Caucasus (Ismail-Zadeh et al., 2007; 2010; 2012; 2020) orogenic regions, the New Madrid (Braile et al., 1982) and the Kutch (Gupta et al., 2001) rift zones. According to the global risk analysis, an area inhabited by more than one billion people is estimated to undergo significant ground shaking by earthquakes for the next 50 years with probability 0.1 (Dilley et al., 2005). Tectonic stress generation (e.g. Aoudia et al., 2007; Ismail-Zadeh et al.,2005, 2010) and stress re-distribution after big earthquakes (e.g., King et al., 1994) are important components in studies of earthquake-prone regions. These studies provide information on the localization of stresses and their changes, which can be used then in hazard assessment. Earthquake simulations can complement the knowledge on tectonic stress release at the faults, which have not been ruptured in the past or if the information on historical earthquakes have not been recorded.

Because historical data on seismicity are usually incomplete and instrumental observations cover a short time interval compared to the duration of the tectonic processes responsible for earthquakes, studies of seismic hazard based only on historical and instrumental observations are lacking the information on large earthquake occurrences. Numerical modelling of seismic processes allows to generate synthetic earthquake catalogues covering long time intervals and provides a basis for reliable estimates of the parameters of the earthquake occurrences (e.g. Soloviev and Ismail-Zadeh, 2003; Rundle et al., 2006; Ismail-Zadeh et al., 2018). Results of the modelling can then be used in assessments of seismic hazard (e.g., Sokolov and Ismail-Zadeh, 2015, 2016). Seismic hazard assessments provide an information on strong ground motions due to potential earthquakes combining the knowledge on seismological, tectonic, geomorphological, and geological features and modelling results. Although a seismic hazard assessment identifies a spatial distribution of strong ground motions and predicts the exceedance of a certain level of ground motions for a certain period of time with a prescribed probability, it does not answer an important questions required for disaster risk management: when does a big earthquake occur?

Earthquake forecasting tries to answer the question, although opinions on the possibilities of forecasts range from the statement that earthquake prediction is intrinsically impossible (Geller et al., 1997) to the statement that prediction is possible, but difficult (e.g., Knopoff, 1999; Keilis-Borok et al., 2001). Earthquake forecasting based on monitoring of precursors (e.g. a ground elevation, water level in boreholes, radon emission, electromagnetic field issues, and animal behaviour) issues an alarm at the time of the abnormal behaviour of the precursors. Alarm-based earthquake prediction methods have been developed for the last several decades. For example, the intermediate-term earthquake prediction method (M8 algorithm; Keilis-Borok and Kossobokov, 1990; Ismail-Zadeh and Kossobokov, 2020) aims to forecast large (magnitude 8 and greater) earthquakes by monitoring and analysis of several parameters of the seismic activity in a region. Another type of earthquake prediction is based on calculating the probabilities of target events within future space-time domains, e.g., the shortterm earthquake probability (STEP) method that uses aftershock statistics to make hourly revisions of the probabilities of strong ground motion (Gerstenberger et al., 2005). 
Although earthquake prediction methods are improving along with geophysical, seismological, and geodetic data analysis and assimilation, the current quality and accuracy of earthquake forecasting are significantly low compared to those of weather forecasting (Bauer et al., 2015). Our knowledge of earthquake physics and earthquake dynamics is still limited to predict large earthquakes with a relatively high accuracy. Meanwhile, even current level of earthquake prediction capacity can be useful for seismic risk assessment and disaster preparedness (Davis, 2012).

\section{Disaster Risks}

Disaster risk is associated with a potential loss of life, injury, damaged assets, which could occur to a community/ society in a specific period of time, determined probabilistically as a function of four indicators: hazard, exposure, vulnerability, and capacity (UNGA, 2016). When an earthquake happens, exposure, vulnerability, and capacity are the key determinants of disaster risk, whereas vulnerability and exposure are the main drivers of disaster losses. Enhancing the capacity (that is, resources, infrastructure, human knowledge and skills, social relationships, leadership, and management) available within a community/society will contribute to significant reduction of risks and strengthen resilience. Changes in any of these indicators alter the risk calculus by increasing or reducing the impacts of disaster risk on affected communities, regions, or countries. Capacity, exposure, and vulnerability patterns vary in space and time, and the geographic patterns of the indicators are unevenly distributed leading to the disproportionate impacts of disasters, especially in disadvantaged regions or countries (Ismail-Zadeh and Cutter, 2015; Ismail-Zadeh, 2018). As geohazards cannot be significantly reduced and exposure increases with economic development, major elements in disaster risk management are the reduction of vulnerability and strengthening capacity.

Many parts of the world are still vulnerable to earthquakes despite the progress made in earthquake research and engineering for the past several decades. For example, seismic risk assessments show that the risk is normally associated with a building resistance to damage due to ground shaking and/or with socio-economic vulnerability rather than with ground motion due to earthquakes (e.g., Babayev et al., 2010; Baker, 2013). With economic and technological development more structural elements become exposed to risks due to geohazards. Risk assessment allows elaborating strategic countermeasure plans for the disaster risk mitigation. An estimation of risks may facilitate a proper choice in a wide variety of safety measures, ranging, in the case of earthquakes, from building codes and insurance to establishment of rescue-and-relief resources.

Our societies should be prepared to extreme geohazard events and subsequent environmental, economic, and financial events associated with them and hence to recover easily from a disaster. Stronger efforts are needed to develop societies resilient to geohazards and related disasters.
Why does a Hazard Event turn to Become a Disaster?

The ongoing global COVID-19 crisis caused by a coronavirus SARS-CoV-2 is a tragic example of how a (biological) hazard event can turn to become a disaster, mainly due to unpreparedness and ignorance of many states, and unawareness of the population about the severity of the hazard and reproductivity of the virus. Although scientific knowledge about coronaviruses and their consequences has been available for years, no preventive measures have been implemented and no strategy to confine the biological hazard and then to mitigate its consequences has been developed (Ismail-Zadeh, 2020). Similarly, earthquakes or other geohazard events turn into a disaster.

Preparedness and awareness are important factors in preventive measures to reduce disaster risks. For example, the level of preparedness for the 2004 Indian Ocean tsunami disaster in many countries was extremely low. Even though an early warning had been sent to the appropriate local authorities of the countries, it is unlikely that it would have been delivered to the public in a timely manner. It is also unlikely that people would have responded to it in appropriate manner, since most of them did not believe that such a disaster could affect them (Ismail-Zadeh and Takeuchi, 2007). In Japan, where the preparedness and awareness of people regarding earthquakes and tsunamis are the highest in the world, the initial data on the earthquake of 11 March 2011 sent to the Tohoku coastal region underestimated the height of tsunami waves. In a response, some people did not evacuate their building and did not move to safer places, because they considered that available sea walls would protect their houses and lives. Unfortunately, the tsunami waves were much higher than expected, and the sea walls were incapable to prevent the great inundation.

A strong earthquake in the plate interior may lead to a disaster if it strikes near a town. And this earthquake will turn to become a disaster in the case of high physical and social vulnerability and low capacity of the town to withstand the earthquake. For example, the energy released by the 2010 Chile M8.8 earthquake was by a factor of about 500 higher than that by the 2010 Haiti M7.0 earthquake. However, the damage and the death toll showed the inverse proportionality: several hundred people lost their lives in the case of the Chile earthquake versus several hundred thousand lives in the case of the Haiti earthquake resulting in a humanitarian catastrophe (IsmailZadeh, 2018). Earthquake disasters happen mainly because of the unwillingness of some local authorities to invest in resistant construction due to various reasons including irresponsibility, ignorance, corruption, the perceived requirement to balance the need for costs versus the increased costs of implementation, local politics, funding availability and other urgent and more politically competitive needs (Ismail-Zadeh et al., 2017).

Multi-hazard concatenated events play a significant role in transformation of hazards into disasters. The 2011 Tohoku M9.0 earthquake, which generated great tsunami waves and flooding, was the largest and most costly disaster in the known history of Japan caused by concatenated hazards events. Although scientists knew about past earthquake and tsunami disasters 
occurred in the region, e.g., the 869 Jogan earthquake, which produced unusually large tsunamis and took up 1000 people in the Sendai plain or tsunamis generated by the 1896 Sanriku earthquake causing 22,000 casualties, the historical experience was not fully utilized to reduce risks. The lessons learned from the Great East Japan earthquake and tsunami disaster include an importance of geophysical observations, improvement of long-term forecast of earthquakes, effective tsunami warning, assessment for future tsunami hazard, and preparedness and education for infrequent hazards (Satake, 2014).

The 1949 Khait (Tajikistan) M7.5 earthquake triggered hundreds of rockslides, which took a heavy toll (more than ten thousand casualties; Evans et al., 2009). The Lake Sarez in Pamir mountain (also in Tajikistan), which formed as a big natural dam due to the 1911 earthquake-triggered rockslides, is one of the most vulnerable objects in the region. In the case of dam failure, e.g., due to an earthquake or other events, over a million of people downstream along the Amu Daria river would be exposed to severe flooding (Stone, 2009).

Scientists knew about historical devastating earthquakes and associated geohazard events, and in many cases, they tried to deliver scientific evidences and relevant information to the decision makers. Just a few examples. Geoscientists alerted about a potential strong earthquake near the capital city of Haiti: “... the Enriquillo fault in Haiti is currently capable of a Mw7.2 earthquake if the entire elastic strain accumulated since the last major earthquake was released in a single event today" (Manaker et al., 2008). It seems that the available information was submerged under other matters like political, financial, and social affairs. It is a challenging task to convince governments to invest in preparedness against disasters, especially it is a difficult task in economically less developed countries. "If about 5 to $10 \%$ of the funds, necessary for recovery and rehabilitation after a disaster, would be spent to mitigate an anticipated earthquake, it could in effect save lives, constructions, and other resources" (Ismail-Zadeh and Takeuchi, 2007). The Sendai Framework for Disaster Risk Reduction 2015-2030 highlights the importance of investments and broader preventive approaches as mentioned in its Priority 3 "Investing in disaster risk reduction for resilience" and Priority 4 "Enhancing disaster preparedness for effective response" (Sendai Framework, 2015).

Disaster risk reduction should be based on firm scientific knowledge, vast information/data, and the systematic development and application of policies, strategies, and practices to minimize vulnerabilities, enhance capacities, and reduce disaster risks throughout a community/society. This will result in avoiding (prevention) or in limiting (mitigation and preparedness) adverse impact of geohazards, within the broad context of sustainable development. Interdisciplinary, coengaged, and co-produced scientific knowledge will provide the basis for better understanding and communicating disaster risks to ensure maximum benefits towards the Sendai Framework's implementation. Science-based disaster risk reduction efforts through integrated research and risk assessments (Cutter et al., 2015) and informed decision-making through disaster science diplomacy efforts (Kontar et al., 2018) would allow for greater actions towards an effective reduction of disaster risks due to geohazards as well as other natural and technological hazards, and would help the governments and societies in mitigating disasters.

Acknowledgements: This editorial paper is based on the dedicated research efforts of interdisciplinary group of scientists involved in natural hazards and disaster science. Special thanks go to Tom Beer, Susan Cutter, John Eichelberger, Harsh Gupta, Katia Kontar, Vladimir Kossobokov, Birgit Mueller, Giuliano Panza, Frank Schilling, Vladimir Sokolov, Alexander Soloviev, Kuni Takeuchi, and Inessa Vorobieva for their valuable contributions and discussions. The German Science Foundation (DFG), the Russian Science Foundation (RSF), the International Union of Geodesy and Geophysics (IUGG), and the International Science Council (ISC) are thanked for support of the research related to disaster risk reduction.

Alik IsmaIL-ZADEH ${ }^{1,2,3}$
Technology, Germany
Institute of Applied Geosciences, Karlsruhe Institute of
${ }^{2}$ Institute of Earthquake Prediction Theory and Mathematical
Geophysics, Russian Academy of Sciences, Moscow, Russia
${ }^{3}$ Secretary-General, International Science Council
E-mail: alik.ismail-zadeh@kit.edu

\section{References}

Aoudia, A., Ismail-Zadeh, A. and Romanelli, F. (2007) Buoyancydriven deformation and contemporary tectonic stress in the lithosphere beneath Central Italy. Terra Nova, v.19(6), pp.490495.

Babayev, G., Ismail-Zadeh, A. and Le Mouël, J-L. (2010) Scenariobased earthquake hazard and risk assessment for Baku (Azerbaijan). Natural Hazards Earth Sys. Sci., v.10, pp.2697-2712.

Baker, J. (2013) Seismology: Quake catcher. Nature, v.498, pp.290292.

Bauer, P., Thorpe, A. and Brunet, G. (2015) The quiet revolution of numerical weather prediction. Nature, v.525, pp.47-55.

Beer, T. and Ismail-Zadeh, A. (Eds.) (2003) Risk Science and Sustainability, Kluwer Academic Publishers, Dordrecht.

Braile, L.W., Hinze, W.J., Keller, G.R., Lidiak, E.G. and Sexton, J.L. (1986) Tectonic development of the New Madrid Rift Complex, Mississippi Embayment, North America. Tectonophysics, v.131, pp.1-21.

Cloetingh, S. and Ehler, T.A. and TOPO-EUROPE Working Group (2020) TOPO-EUROPE - ILP's program on coupled deep Earth and surface processes in continental Europe and its margins. Jour. Geol. Soc. India, v.95, pp.1-6.

Cutter, S., Ismail-Zadeh, A., Alcántara-Ayala, I., Altan, O., Baker, D.N, Briceño, S., Gupta, H., et al. (2015) Pool knowledge to stem losses from disasters. Nature, v.522, pp.277-279.

Davis, C.A. (2012) Loss functions for temporal and spatial optimizing of earthquake prediction and disaster preparedness. Pure Appl. Geophys., v.169(11), pp.1989-2010.

Dilley, M., Chen, R.S., Deichmann, W., Lerner-Lam, A.L. and Arnold, M. (2005) Natural Disaster Hotspots: A Global Risk Analysis. The World Bank, Washington DC.

Evans, S., Roberts, N., Ischuk, A., Delaney, K., Morozova, G., and Tutubalina, O. (2009) Landslides triggered by the 1949 Khait 
Earthquake, Tajikistan, and associated loss of life. Eng. Geology, v.109, pp.195-212.

Geller, R.J., Jackson, D.D., Kagan, Y.Y. and Mulargia, F. (1997) Earthquakes cannot be predicted. Science, v.275, pp.1616-1617.

Gerstenberger, M.C., Wiemer, S., Jones, L.M. and Reasenberg, P.A. (2005) Real-time forecasts of tomorrow's earthquakes in California. Nature, v.435, pp.328-331.

Gupta, H.K., Purnachandra Rao, N., Rastogi, B.K., Sarkar, D. (2001) The deadliest intraplate earthquake. Science, v.291, pp.2101-2102.

Ismail-Zadeh, A. (2018) Earthquake hazard modelling and forecasting for disaster risk reduction. In: Vacareanu, R., Ionescu, C. (Eds) Seismic Hazard and Risk Assessment.Springer, Cham, pp.3-21.

Ismail-Zadeh, A. (2020) Placing scientific knowledge, preparedness and public awareness at the core of disaster risk policy. International Sciences Council, Paris. Available at: https://council.science/ current/blog/placing-scientific-knowledge-preparedness-andpublic-awareness-at-the-core-of-disaster-risk-policy/ (retrieved 16.07.2020).

Ismail-Zadeh, A. and Cutter, S. (Eds.) (2015) Disaster Risks Research and Assessment to Promote Risk Reduction and Management. ICSU\&ISSC, Paris. Available at: https://council.science/wpcontent/uploads/2015/03/Report_RiskReduction_WCDRR_ 2015.pdf (retrieved on 16.07.2020).

Ismail-Zadeh, A. and Kossobokov, V.G. (2020) Earthquake prediction, M8 algorithm. In: Gupta, H. (Ed.), Encyclopaedia of Solid Earth Geophysics, Springer Nature, Switzerland AG. DOI:10.1007/9783-030-10475-7_157-1.

Ismail-Zadeh, A. and Takeuchi, K. (2007) Preventive disaster management of extreme natural events. Natural Hazards, v.42, pp.459-467.

Ismail-Zadeh, A., Mueller, B. and Schubert, G. (2005) Threedimensional modeling of present-day tectonic stress beneath the earthquake-prone southeastern Carpathians based on integrated analysis of seismic, heat flow, and gravity observations. Phys. Earth Planet. Inter., v.149, pp.81-98.

Ismail-Zadeh, A., Le Mouël, J-L., Soloviev, A., Tapponnier, P. and Vorovieva, I. (2007) Numerical modeling of crustal block-andfault dynamics, earthquakes and slip rates in the Tibet-Himalayan region. Earth Planet. Sci. Lett., v.258, pp.465-485.

Ismail-Zadeh, A., Aoudia, A. and Panza, G. (2010) Three-dimensional numerical modeling of contemporary mantle flow and tectonic stress beneath the Central Mediterranean. Tectonophysics, v.482, pp.226-236.

Ismail-Zadeh, A., Matenco, L., Radulian, M., Cloetingh, S. and Panza, G. (2012) Geodynamic and intermediate-depth seismicity in Vrancea (the south-eastern Carpathians): Current state-of-the-art. Tectonophysics, v.530-531, pp.50-79.

Ismail-Zadeh, A., Urrutia Fucugauchi, J., Kijko, A., Takeuchi, K., Zaliapin, I. (Eds.) (2014) Extreme Natural Hazards, Disaster Risks and Societal Implications. Cambridge University Press, Cambridge.

Ismail-Zadeh, A., Cutter, S.L., Takeuchi, K. and Paton, D. (2017) Forging a paradigm shift in disaster science. Natural Hazards, v.86, pp.969-988.

Ismail-Zadeh, A., Soloviev, A., Sokolov, V., Vorobieva, I., Muller, B. and Schilling, F. (2018) Quantitative modeling of the lithosphere dynamics, earthquakes and seismic hazard. Tectonophysics, v.746, pp.624-647.
Ismail-Zadeh, A., Adamia, S., Chabukiani, A., Chelidze, T., Cloetingh, S., Floyd, M., et al. (2020) Geodynamics, seismicity, and seismic hazards of the Caucasus. Earth Sci. Rev., v.207, pp.103222.

Keilis-Borok, V.I., Kossobokov, V.G. (1990) Premonitory activation of earthquake flow: algorithm M8. Phys. Earth Planet. Internat., v.61, pp.73-83.

Keilis-Borok, V., Ismail-Zadeh, A., Kossobokov, V. and Shebalin, P. (2001) Non-linear dynamics of the lithosphere and intermediateterm earthquake prediction. Tectonophysics, v.338(3-4), pp.247259.

King, G.C.P., Stein, R.S. and Lin, J. (1994) Static stress changes and the triggering of earthquakes. Bull. Seismol. Soc. Amer., v.84, pp.935-953.

Knopoff, L. (1999) Earthquake prediction is difficult but not impossible. Nature, DOI:10.1038/nature28113.

Kontar, Y.Y., Beer, T., Berkman, P.A., Eichelberger, J.C., Ismail-Zadeh, A., Kelman, I., et al. (2018) Disaster-related science diplomacy: advancing global resilience through international scientific collaborations. AAAS Science \& Diplomacy 7(2), http:// www.sciencediplomacy.org/article/2018/disaster-related-sciencediplomacy-advancing-global-resilience-through-international.

Manaker, D.M., Calais, E., Freed, A.M., Ali, S.T., Przybylski, P., Mattioli G. et al. (2008) Interseismic plate coupling and strain partitioning in the Northeastern Caribbean. Geophys. Jour. Internat., v.174, pp.889-903.

Rundle, P.B., Rundle, J.B., Tiampo, K.F., Donnellan, A., Turcotte, D.L. (2006) Virtual California: Fault model, frictional parameters, application. Pure Appl. Geophys., v.163, pp.1819-1846.

Satake K. (2014) The 2011 Tohoku, Japan, earthquake and tsunami. In: Ismail-Zadeh, A., Urritia Fucugauchi, J., Kijko, A., Takeuchi K. and Zaliapin, I. (Eds.), Extreme Natural Hazards, Disaster Risks and Societal Implications, Cambridge University Press, Cambridge, pp.310-321.

Sendai Framework (2015) Sendai Framework for Disaster Risk Reduction 2015-2030. United Nations Officer for Disaster Risk Reduction, Geneva. Available at: https://www.preventionweb.net/ files/43291_sendaiframeworkfordrren.pdf (retrieved on 16.07.2020).

Sokolov, V., Ismail-Zadeh, A. (2015) Seismic hazard from instrumentally recorded, historical and simulated earthquakes: Application to the Tibet-Himalayan region. Tectonophysics, v.657, pp.187-204.

Sokolov, V., Ismail-Zadeh, A. (2016) On the use of multiple-site estimations in probabilistic seismic hazard assessment. Bull. Seismol. Soc. Amer., v.106(5), pp.2233-2243.

Soloviev, A.A., Ismail-Zadeh, A.T. (2003) Models of dynamics of block-and-fault systems. In: Keilis-Borok, V.I., Soloviev, A.A. (Eds.), Nonlinear Dynamics of the Lithosphere and Earthquake Prediction, Springer, Heidelberg, pp.69-138.

Stern, R.J. (2002) Subduction zones. Rev. Geophys., v.40(4), pp.1012, DOI: 10.1029/2001RG000108.

Stone, R. (2009) Peril in the Pamirs. Science, v.326, pp.16141617.

UNGA (2016) Report of the open-ended intergovernmental expert working group on indicators and terminology relating to disaster risk reduction. United Nations General Assembly, New York. Available at: https://www.preventionweb.net/files/50683_oiewg reportenglish.pdf (retrieved on 16.7.2020). 